\title{
FRICTION AND WEAR BEHAVIOUR OF ULEXITE AND CASHEW IN AUTOMOTIVE BRAKE PADS
}

\author{
ODPORNOST PROTI TRENJU IN OBRABI AVTOMOBILSKIH \\ ZAVORNIH OBLOG Z ULEKSITOM IN PRAHOM IZ INDIJSKEGA \\ OREHA
}

\author{
İlker Sugözüi ${ }^{1}$ İbrahim Mutlu², Ahmet Keskin ${ }^{3}$ \\ ${ }^{1}$ Mersin University, Tarsus Technology Faculty, Mersin, Turkey \\ 2Afyon Kocatepe University, Technology Faculty, Afyonkarahisar, Turkey \\ ${ }^{3}$ Abant Izzet Baysal University, Bolu Vocational School, Bolu, Turkey \\ ibrahimmutlu@aku.edu.tr
}

Prejem rokopisa - received: 2014-09-14; sprejem za objavo - accepted for publication: 2014-10-15

\begin{abstract}
In the experimental studies, ulexite and cashew were investigated as new materials in brake pads. A newly formulated brake-pad material with five different ingredients was produced using ulexite. Tribological properties of the friction materials were obtained using the brake-test equipment. The friction and wear characteristics of the samples in contact with a disk made of cast iron were studied. The change in the friction coefficient, the temperature of the friction surface and the amount of the wear were examined to assess the performance of these samples. In addition, microstructural characterizations of the braking pads were carried out using scanning electron microscopy (SEM). The results showed that the friction materials containing ulexite and cashew have an important effect on the friction stability and fade resistance. The strategy proposed in this paper can be considered for the alternative friction materials where ulexite and cashew can be used as friction materials in the brake pads.

Keywords: brake pad, composite materials, friction coefficient, ulexite, cashew
\end{abstract}

Preiskovan je bil vpliv uleksita in prahu iz indijskega oreha kot novega materiala v zavornih oblogah. Novo zasnovani material za zavorne obloge iz petih sestavin je bil izdelan z uporabo uleksita. Tribološke lastnosti tornega materiala so bile preizkušene na napravi za preizkus zavor. Preučevano je bilo trenje in značilnosti obrabe vzorcev v stiku z diskom iz sive litine. Za oceno zmogljivosti vzorcev so bile preiskane spremembe koeficienta trenja, izmerjena temperatura na površini stika in količina obrabe. Z vrstičnim elektronskim mikroskopom (SEM) so bile dodatno preiskane mikrostrukturne značilnosti zavornih oblog. Rezultati so pokazali, da imajo torni materiali, ki vsebujejo uleksit in prah indijskega oreha, pomemben vpliv na stabilnost trenja in odpornost proti odpovedi zavor pri višjih temperaturah. V tem članku predlagana usmeritev se lahko upošteva kot nadomestni torni material za zavorne obloge na osnovi uleksita in prahu iz indijskega oreha.

Ključne besede: zavorne obloge, kompozitni material, koeficient trenja, uleksit, prah iz indijskega oreha

\section{INTRODUCTION}

The friction element of an automotive brake system is one of the most important composite materials and generally consists of more than ten ingredients. This is because the friction materials have to provide a steady friction force, a reliable strength, and a good wear resistance in a broad range of braking circumstances. ${ }^{1}$ Recently, some studies have shown that the most fatal accidents on the roads happen because of failed brake systems. ${ }^{2,3}$ The performance of a brake system in a vehicle is mainly determined by the tribological characteristics of the friction couple, composed of a gray-iron disk (or drum) and friction materials. ${ }^{1,4}$

The most important property of the friction materials is a high friction coefficient so that they remain stable under high forces and, especially, at high temperatures. ${ }^{2,3}$ The function of the brakes is to change the kinetic energy into the heat energy by absorbing it and releasing it into the atmosphere. If the generated heat exceeds the capacity of a brake, there is a decrease in the friction coefficient of the brake pads. When brake pads are ex- posed to high temperatures for long time, they are damaged. This damage results in a decrease in the brake performance, a high brake-pad wear or noise., ${ }^{3,5}$ A great deal of effort has been made to develop friction materials with optimized tribological characteristics regardless of the type of braking conditions. ${ }^{3,4}$

Currently, more than 800 raw materials cited in the literature are used to produce friction materials for the commercial brakes. ${ }^{6,7}$ Most automotive friction materials contain a phenolic-resin binder with additions of mineral fibers, fillers, friction-modifying compounds, abrasives and metallic particles to modify the heat-flow characteristics. ${ }^{8,9}$ In a simplistic sense, fibers are included for their friction properties, heat resistance and thermal conductivity. The physical and chemical properties of a resin affect the wear process and friction characteristics of the friction material. In addition, a straight phenolic resin was used for brake friction materials and various modified resins are available to improve the compressibility, thermal stability, damping capacity and mechanical strength. ${ }^{10}$ They play an important function of 
toughening and strengthening the binder, which is quite brittle in its pure form. ${ }^{11}$ Numerous compositions of friction materials have been developed, largely by empirical testing. ${ }^{8}{ }^{8}$ Several projects were conducted to investigate the friction materials that could improve the braking effectiveness, while also contributing to the energy efficiency. ${ }^{12}$ In the literature, there are a lot of studies about using new materials for the brake pads in order to increase the braking performance. ${ }^{13-18}$

Raw and refined borates are used in ceramic glazes; thin coatings are applied onto ceramics. Borates are consumed mostly in the glass and fiberglass industry. Borates help the glass formation, reduce the thermal expansion and give resistance and durability to the ceramics. An addition of borates reduces the material stresses caused by the temperature gradients, thus making it more resistant to breaking. Borates are also used in borosilicate glasses. Borosilicate glass is not only highly resistant to a chemical attack, but it also has a very low coefficient of thermal expansion and, as a result, a high resistance to thermal shock. This thermalshock resistance exceeds that of the ordinary glass by a factor of three. ${ }^{19}$

Ulexite is a mineral that combines calcium, sodium, water molecules and boron in a complicated arrangement with the following formula: $\mathrm{NaCaB}_{5} \mathrm{O}_{9} \cdot 8 \mathrm{H}_{2} \mathrm{O}$. It consists of thin crystals that act like optical fibers. On the surface, ulexite takes the shape of soft-looking masses and is often called "cotton ball". This form also occurs beneath the surface in veins similar to chrysotile, in which the crystal fibers run across the width of the veins. ${ }^{20}$

Cashew friction dust is made of CNSL (cashew nut-shell liquid). Due to its friction particles it is used as a stability agent in brake products; it has a resilient nature, acting as a cushioning agent of the engaging property of the lining. Further, it is easily decomposed on the surface of a brake lining at various elevated temperatures controlling the wear and acting as a protective element by prohibiting the generation of excessive temperature. It also easily absorbs the heat and disperses it accross the whole area of the friction material. It is mainly used as one of the prime raw materials for heavy-automobile non-asbestos and asbestos brake linings. It is also used for clutch facings and disc pads. $^{21,22}$

In order to test the performance of ulexite in automotive friction materials, ulexite is sifted after grinding to obtain dust as raw boron products. In the case of ulexite and cashew being used together, when the amount of ulexite is increased, the amount of cashew is decreased. Five kinds of samples with different ingredients were designed. The tribological properties of these samples were determined using brake-test equipment. The friction tests were performed up to $400{ }^{\circ} \mathrm{C}$. The change in the friction coefficient, the temperature of friction surface and the amount of wear were examined to identify the performance of these samples. In addition, microstructural characterizations of the braking pads were carried out using scanning electron microscopy (SEM). The results showed that the friction materials containing ulexite have an important effect on the friction stability and fade resistance. Due to the heat and abrasion resistance and the ability to reduce the thermal expansion of ulexite, the use of this material in brake pads can be attractive.

\section{MATERIALS AND METHODS}

In this study, a new automotive-brake friction material was developed using an addition of ulexite. The influence of ulexite on the brake's friction characteristics was especially examined. The friction materials investigated in this study were variations of a NAO (non-asbestos organic)-type material containing different ingredients including ulexite. Ulexite was obtained from Balikesir, the Bigadiç mine of Etibank in Turkey. The composition of the ulexite studied in this work is shown in Table 1.

Table 1: Composition of ulexite studied in this work ${ }^{19}$ Tabela 1: Sestava uleksita, uporabljenega v tej študiji ${ }^{19}$

\begin{tabular}{|c|c|c|c|c|}
\hline Element & $\mathrm{B}_{2} \mathrm{O}_{3}$ & $\mathrm{CaO}$ & $\mathrm{Na}_{2} \mathrm{O}$ & $\mathrm{SiO}_{2}$ \\
\hline$w / \%$ & $24-38$ & $18-24$ & $2-7$ & $4-13$ \\
\hline
\end{tabular}

Five different samples were produced. These samples contained ulexite, phenolic resin, steel fiber, copper, aluminium oxide, graphite, brass particles, cashew and barite. The friction-coefficient and temperature values were stored in a databank. Friction coefficient/temperature/time graphs and the mean coefficients of friction were obtained to identify the friction characteristics. An analytical balance was used to weigh the ingredients. The friction-material samples were produced in the conventional procedure for a dry formulation following dry mixing, pre-forming and hot pressing. These ingredients were mixed for 10 min using a commercial blender. The final mixture was loaded into a one-inch square (small samples) mold for pre-forming under a pressure of $9.8 \mathrm{MPa}$. The pre-formed samples were put

Table 2: Ingredients of the samples $(w / \%)$

Tabela 2: Vsebnosti v vzorcih $(w / \%)$

\begin{tabular}{|l|c|c|c|c|c|}
\hline \multicolumn{1}{|c|}{ Sample code } & $\begin{array}{c}\text { UC-4 } \\
\text { UCH-4 }\end{array}$ & $\begin{array}{c}\text { UC-8 } \\
\text { UCH-8 }\end{array}$ & $\begin{array}{c}\text { UC-12 } \\
\text { UCH-12 }\end{array}$ & $\begin{array}{c}\text { UC-16 } \\
\text { UCH-16 }\end{array}$ & $\begin{array}{c}\text { UC-20 } \\
\text { UCH-20 }\end{array}$ \\
\hline Phenolic resin & 22 & 22 & 22 & 22 & 22 \\
\hline Steel fibers & 15 & 15 & 15 & 15 & 15 \\
\hline $\mathrm{Al}_{2} \mathrm{O}_{3}$ & 3 & 3 & 3 & 3 & 3 \\
\hline Brass particles & 5 & 5 & 5 & 5 & 5 \\
\hline Graphite & 3 & 3 & 3 & 3 & 3 \\
\hline Barite & 20 & 20 & 20 & 20 & 20 \\
\hline Cu particles & 8 & 8 & 8 & 8 & 8 \\
\hline Cashew & 4 & 8 & 12 & 16 & 20 \\
\hline Ulexite & 20 & 16 & 12 & 8 & 4 \\
\hline Total & 100 & 100 & 100 & 100 & 100 \\
\hline
\end{tabular}


into a hot-pressing mold and pressed at a pressure of 14.7 $\mathrm{MPa}$ and at $180{ }^{\circ} \mathrm{C}$ for $15 \mathrm{~min}$. During the hot-pressing process, pressure was released several times to release the gases that evolved from the cross-linking reaction (polycondensation) of the phenolic resin. Detailed conditions for each manufacturing step can be found in the author's other study. ${ }^{23}$ The compositions of the friction materials studied in this work are shown in Table 2.

In order to define the friction coefficients of the automotive brake pad under different temperatures, a test device was designed and manufactured. Figure 1 shows a schematic view of the brake tester used in this study.

Using a real brake-disc-type tester, the frictioncoefficient characteristics of a pad next to the disc made of cast iron were investigated by changing the pad. The test sample was mounted on the hydraulic pressure and pressed against the flat surface of the rotating disc. Before performing the friction-coefficient tests, the surfaces of the test samples and the cast iron discs were ground with 320-grit sandpaper. The normal load was varied to achieve a constant friction force. The braking tests were carried out at a pressure of $1.05 \mathrm{MPa}$, a velocity of $6 \mathrm{~ms}^{-1}$ and at temperatures from $50{ }^{\circ} \mathrm{C}$ to 400 ${ }^{\circ} \mathrm{C}$ for $500 \mathrm{~s}$. An electrical heater was used in order to achieve the friction-surface temperature of $400{ }^{\circ} \mathrm{C}$. The temperature and friction-coefficient values were stored in the databank. The tests were repeated three times for each sample.

Friction coefficient/temperature/time graphs were obtained to identify the effects of these variables. The friction coefficient of the surface-material couple needs to be high and stable. The friction coefficient was calculated by measuring the normal and tangential pressures throughout the test $500 \mathrm{~s}$. It was expressed as the mean value of the entire braking dependence during the friction-coefficient test. The specific wear rate was determined with the mass method following the Turkish

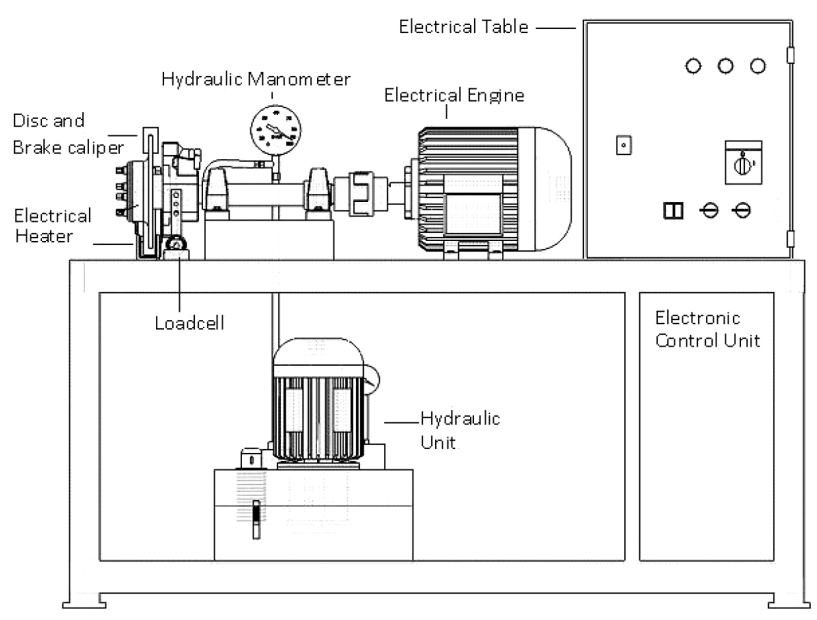

Figure 1: Schematic view of the brake tester

Slika 1: Shematski prikaz preizkuševalnika zavor
Standard (TS 555) and British Standard (BS AU142) and calculated with the following Equation (1):

$$
V=\left(m_{1}-m_{2}\right) /\left(L f_{\mathrm{m}} \rho\right)
$$

where $V$ is the specific wear $\left(\mathrm{mm}^{3} / \mathrm{MJ}\right), m_{1}$ is the mass of the brake pad before the testing $(\mathrm{kg}), m_{2}$ is the mass of the brake pad after the testing $(\mathrm{kg}), L$ is the friction distance calculated using the number of revolutions and the radius of the disc $(\mathrm{m}), f_{\mathrm{m}}$ is the average friction force $(\mathrm{N})$ and $\rho$ is the density of the brake pad $\left(\mathrm{kg} / \mathrm{mm}^{3}\right){ }^{24,25}$

\section{RESULTS AND DISCUSSION}

\subsection{Effect of the temperature on the friction perfor- mance}

In the present study, 10 samples were used. These samples contained copper particles, phenolic resin, $\mathrm{Al}_{2} \mathrm{O}_{3}$, steel fibers, brass particles, graphite, barite, ulexite and cashew (Table 2). Only half of the samples (with the $\mathrm{UCH}$ indices) were heat treated for $4 \mathrm{~h}$ at a temperature of $180{ }^{\circ} \mathrm{C}$. The remaining 5 samples were untreated (with the UC indices). These samples included 4-20\% ulexite and 20-4\% cashew, respectively, and the mean friction coefficient ranged from 0.394 to 0.454 .

When the coefficient of friction $(\mu)$ was studied it varied significantly during the initial stage of the testing. This can be attributed to the fact that the size of the contact area increased and the friction layer was developed on the surface. In order to determine the variations in the friction coefficient and the temperature of the friction surface with the testing time of the samples, the tests were performed at applied temperatures from $50{ }^{\circ} \mathrm{C}$ to $400{ }^{\circ} \mathrm{C}$ (Figures 2 to 6 ). As seen from these figures, the friction coefficients show different features depending on the content.

Generally, the friction-coefficient value gradually increases for all the samples until the $100 \mathrm{~s}$ and then gradually decreases after the $400 \mathrm{~s}$ (Figures 2 to 6). The reason of the increasing friction coefficient is the contact of the metallic material with the disc surface. The wear of the ingredients of the metallic materials is tested.

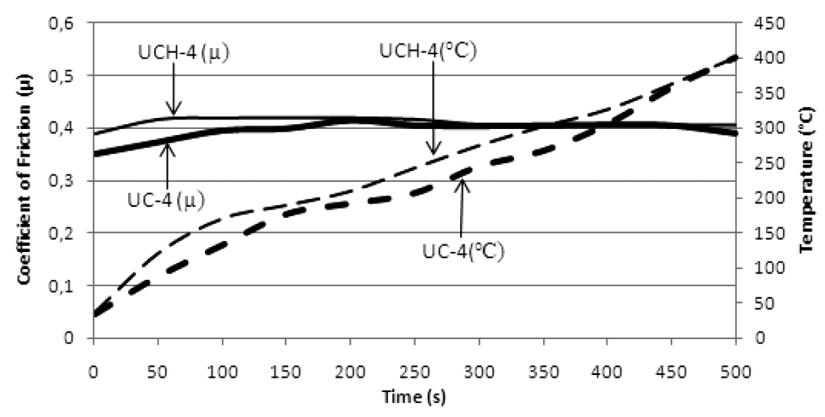

Figure 2: Change in the friction coefficient versus the temperature as a function of time for samples UC-4 and UCH-4

Slika 2: Spreminjanje koeficienta trenja $\mathrm{v}$ odvisnosti od temperature in časa pri vzorcih UC-4 in UCH-4 


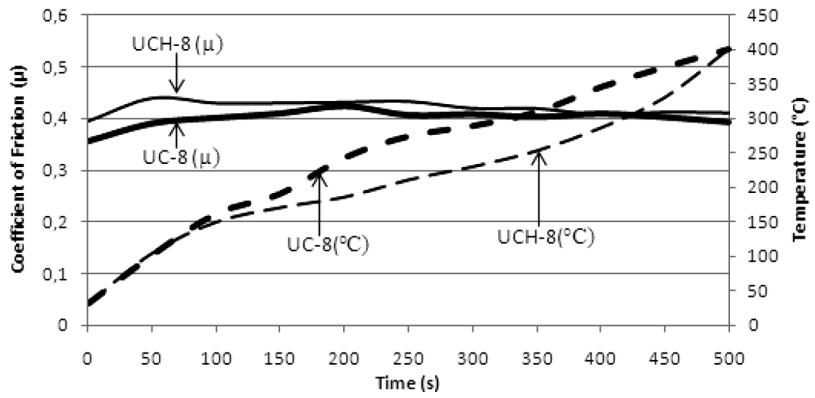

Figure 3: Change in the friction coefficient versus the temperature as a function of time for samples UC-8 and UCH-8

Slika 3: Spreminjanje koeficienta trenja v odvisnosti od temperature in časa pri vzorcih UC-8 in UCH-8

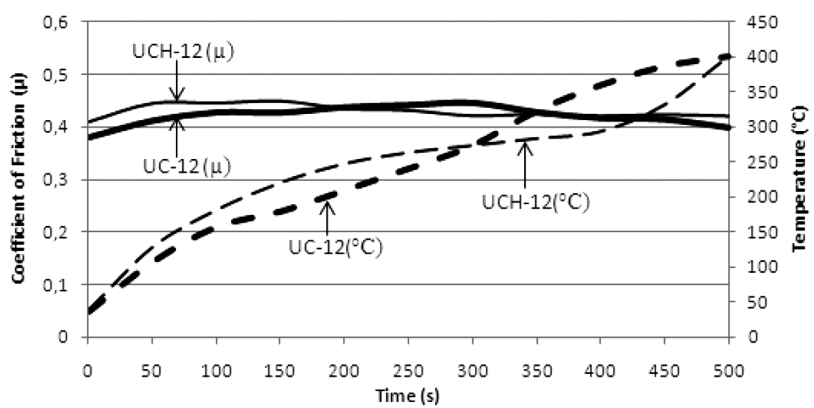

Figure 4: Change in the friction coefficient versus the temperature as a function of time for samples UC-12 and UCH-12

Slika 4: Spreminjanje koeficienta trenja v odvisnosti od temperature in časa pri vzorcih UC-12 in UCH-12

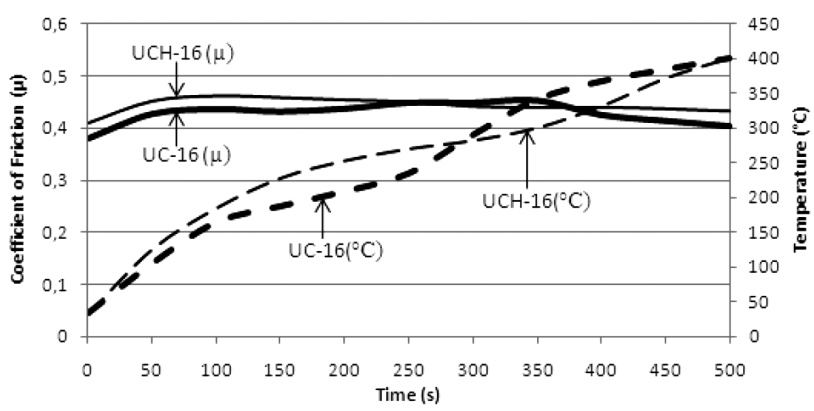

Figure 5: Change in the friction coefficient versus the temperature as a function of time for samples UC-16 and UCH-16

Slika 5: Spreminjanje koeficienta trenja v odvisnosti od temperature in časa pri vzorcih UC-16 in UCH-16

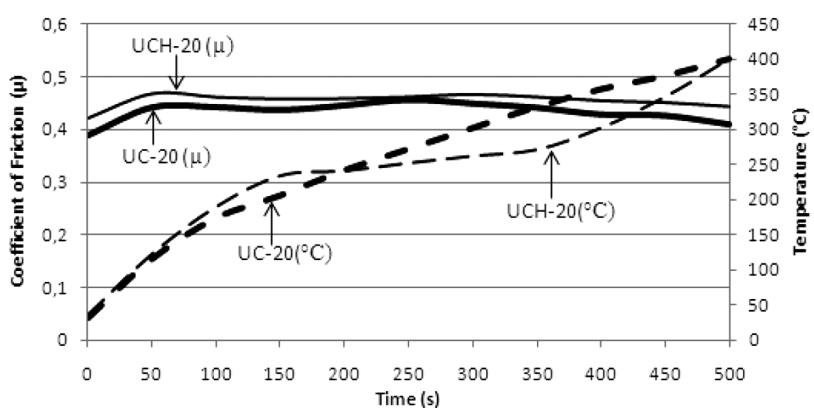

Figure 6: Change in the friction coefficient versus the temperature as a function of time for samples UC-20 and UCH-20

Slika 6: Spreminjanje koeficienta trenja v odvisnosti od temperature in časa pri vzorcih UC-20 in UCH-20
Therefore, these metallic materials detach from the surface of the brake pad and the friction coefficient decreases. This phenomenon continues until new friction surfaces appear. A rapid increase in the coefficient of friction may lead to a rapid increase in the temperature of the friction surface.

It was found that the friction coefficient decreases with the increasing testing temperature. Generally, the friction coefficient decreased between $350{ }^{\circ} \mathrm{C}$ and 400 ${ }^{\circ} \mathrm{C}$ due to the softening of the phenolic resin (Figures 2 to 6). As a result, fading occurred during the braking action. Furthermore, with the increasing temperatures, the ingredients in the brake pads affected each other due to a faster diffusion. This phenomenon is called the thermal fade. ${ }^{4}$ Therefore, one can say that the samples remained unchanged only up to the temperature of 400 ${ }^{\circ} \mathrm{C}$. There was an increase in $\mu$ before the $200 \mathrm{~s}$, followed by a decrease just after the $350 \mathrm{~s}$ when $\mu$ was almost constant for the UCH-4, UCH-16 and UCH-20 samples (Figures 2, 5 and 6). This degradation is somewhat slow, having slight fluctuations. By the $300 \mathrm{~s}$, as a result of the friction, a temperature of $300-350{ }^{\circ} \mathrm{C}$ was achieved on the friction surface.

As seen from these figures, it is understood that all the heat-treated samples (UCH) have higher frictioncoefficient values and more stable friction coefficients than the others. The differences between the friction coefficients of the UC samples and the UCH samples are obvious especially at the beginning and after the $400 \mathrm{~s}$. The difference at the initial state shows a good fit of the heat-treated samples to the surface. At the states after the $400 \mathrm{~s}$ the heat-treated samples have a lower temperature then the others at this time (Figures 3 to 6). Thus, the friction coefficients of the UC samples decreased due to the increase in the temperature. ${ }^{26}$ It is observed that the friction-coefficient and temperature values of the non-heat-treated samples quickly change and fluctuate. As a result, it can be said that heat treatment makes the friction coefficients stable and increases the frictioncoefficient values.

Nonetheless, it should be noted that a good stability of $\mu$ is achieved using the samples under the working condition considered. These results are consistent with the behavior of the friction coefficients of all the samples. Therefore, if a $\mu$ value of $0.39-0.45$ is desired, additions of both ulexite and cashew can be used in the brake pads in the amounts of 4-20\%. Furthermore, if the stability of $\mu$ is desired and $\mu$ has higher values, the $\mathrm{UCH}-20$ sample is suggested as the best material for the brake pads when compared to the others. Some middle vibrations and noise were observed during the testing with the friction assessment and screening test (FAST). This vibration was typically observed at the beginning of the test, before a stable friction layer was developed. 


\subsection{Microstructural characterization of friction surfa-} ces

Apparently, friction layers are formed by the wear particles generated during the friction. The chemistry and structure of a friction layer depend on the bulk materials (lining and disc), the testing conditions and the environment. The role of the friction layer may vary depending on its characteristics. ${ }^{27,28}$ The SEM micrographs of the braking-pad surfaces after the braking test are shown in Figures $\mathbf{7}$ and $\mathbf{8}$. The friction surfaces of the samples were characterized using SEM (LEO 1430 VP). The sample surfaces for the SEM observations were always coated with carbon. There are micro-voids on the surfaces of almost all the samples. Micro-voids consist of the metallic particles detached during the friction.

It is seen from Figures $\mathbf{7}$ and $\mathbf{8}$ (UC-8 and UCH-4) that larger micro-voids occurred in the samples due to detached metallic particles. As seen in these figures, some particles are detached from the body causing micro-voids. The micro-voids on the surfaces of the samples can be classified as smaller or bigger in size. The bigger micro-voids were formed due to the pitting of the metallic particles during the friction. The worn metallic particles imply that they actively participated in the friction during the braking test. It is known that if the coherent surface of a metal component is bigger, the friction and wear will be increased. In addition to micro-voids, there are some micro-cracks on the surfaces. It is also observed that $\mathrm{Al}_{2} \mathrm{O}_{3}$ particles are distributed homogeneously, therefore, contributing to the effectiveness of the friction surfaces.

Several characteristic features can be observed on the friction surfaces of the pads. White spots are seen on Figure 7 (UC-8 and UC-20). Dark areas can also be seen in Figures 7 and 8 (UC-8 and UCH-4). A more loose contact on the trailing edge facilitates the access of air and an uneven wear related to a higher oxidation (a burn-off) of the phenolic resin. This is due to the distribution of the friction force over a pad surface. ${ }^{28}$ When the pads heat up during the braking, the resin tends to expand at very high temperatures and turn into glassy carbon. Carbonized resins weaken the matrix and accelerate the pad wear (Figure 7, UC-8 and UC-16). ${ }^{28,29}$ The glassy phase loses its support and is torn off from the surface by the shear force. ${ }^{30}$ Figures 7 and $\mathbf{8}$ relating to UC-12, UC-16, UC-20, UCH-8 and UCH-12 (from the SEM) show thick friction layers developed on the surfaces of the pads.

In this particular case, the friction layer covering a friction surface diminishes the abrasive effect of the glassy phase by eliminating the sharp edge of the glass and smoothing the friction surface. Hard glassy particles typically act as an abrasive element and scratch off the
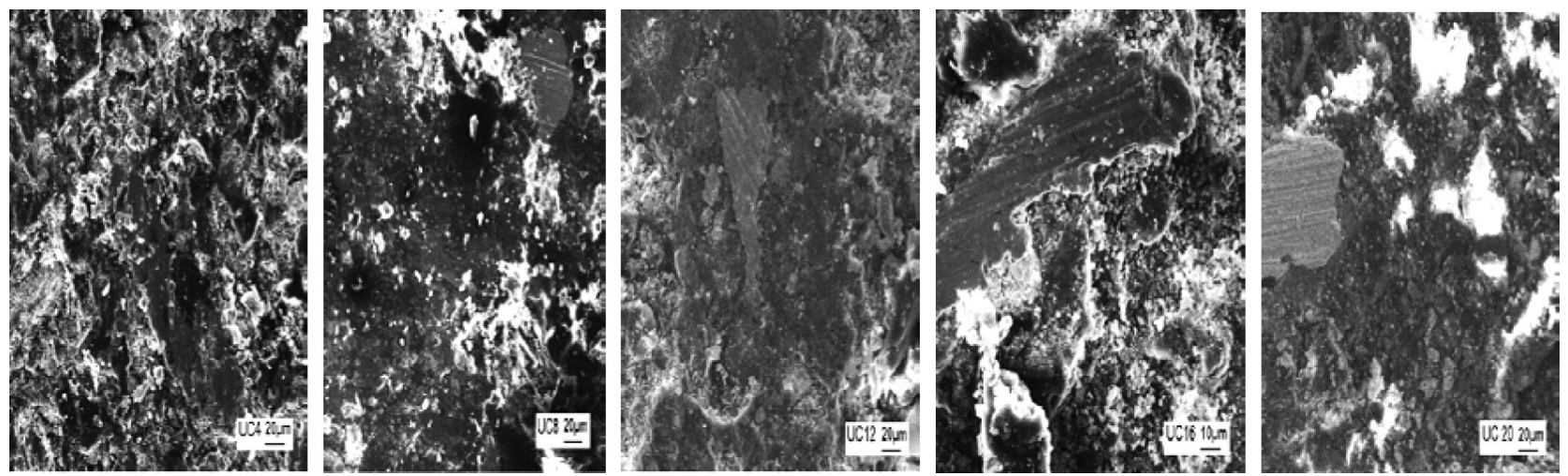

Figure 7: SEM micrographs of brake-pad samples with the UC code Slika 7: SEM-posnetki vzorcev zavornih oblog z oznako UC
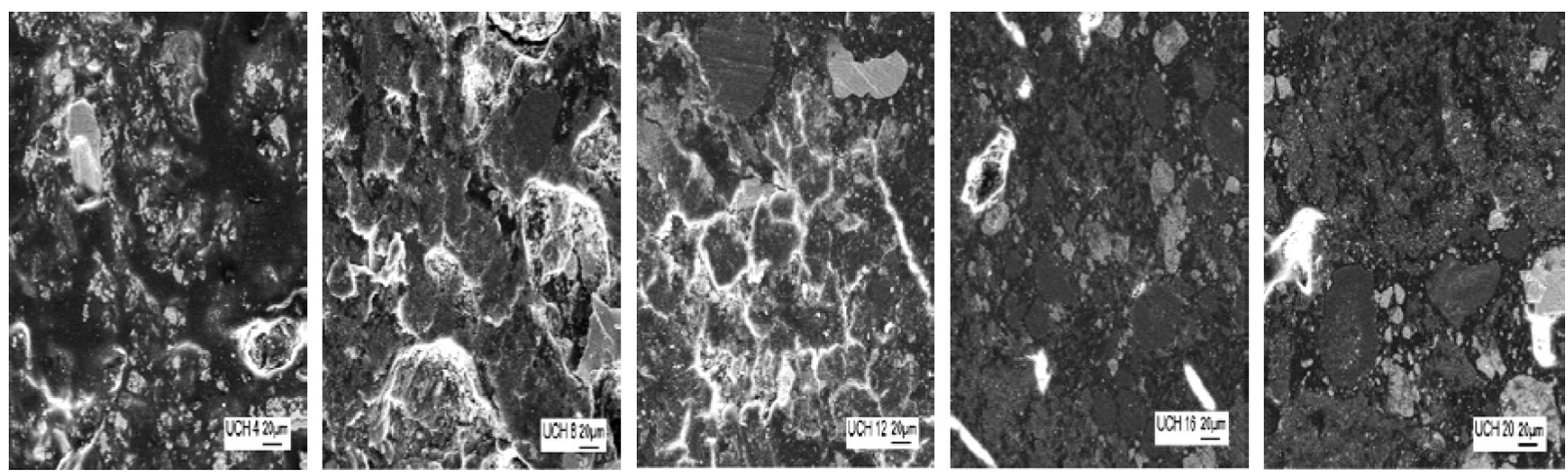

Figure 8: SEM micrographs of brake-pad samples with the UCH code

Slika 8: SEM-posnetki vzorcev zavornih oblog z oznako UCH 
cast-iron-disc counter face and the material adhering to it. ${ }^{28}$ Apparently, the carbonaceous matrix was formed of graphite, coke and degraded phenolic resin. The ingredient with the plastic-deformation capability developed a flake-like feature after the friction experiment (Figures 7 and 8; UC-16, UC-20, UCH-8 and UCH-12).

All matters were homogeneously distributed in the matrix and, therefore, very few micro-voids were observed in the structures (Figures 7 and 8; UC-4, UC-8, $\mathrm{UC}-12, \mathrm{UCH}-8$ and $\mathrm{UCH}-20$ ). The friction process is characterized by the development of friction debris. Such debris adheres to the friction surface and forms a friction layer easily visible when examining a sample surface after the testing (FAST) (Figures 7 and 8; UC-16, UC-20, UCH-4 and UCH-8). A systematic analysis of the surfaces of the composite materials indicated that the friction process dominantly occurred on the friction layer, which eventually covered the top of the bulk. Well-developed friction layers on the friction surfaces as well as their morphologies are easily visible. Detailed views of the friction surfaces including the information about the friction layers are shown in Figures 7 and 8 . Diffusion occurred in the $\mathrm{Cu}$ particles located in the friction layers. Brighter areas marked as $\mathrm{Cu}$ in Figures 7 and 8 (UC-4, UC-8, UC-16 and $\mathrm{UCH}-12$ ) represent the regions where $\mathrm{Cu}$ interacted with the friction layers. ${ }^{31}$

\subsection{Wear behaviour}

Table 3 gives the mean coefficients of friction, the standard deviations of coefficients of friction, densities, hardness values and the specific wear rates of the tested samples. As can be seen from Table 3 , the friction coefficients are in the appropriate category according to the Turkish Standard TS 555 and British Standard BS AU142. Also, the standard deviations are very small, which means that the materials have stable friction characteristics.

Table 3: Typical characteristics of the brake pads used in this study Tabela 3: Značilnosti zavornih oblog, uporabljenih v tej študiji

\begin{tabular}{|c|c|c|c|c|c|}
\hline $\begin{array}{c}\text { Sample } \\
\text { code }\end{array}$ & $\begin{array}{c}\text { Mean } \\
\text { coeffi- } \\
\text { cient of } \\
\text { friction }\end{array}$ & $\begin{array}{c}\text { Standard } \\
\text { deviation }\end{array}$ & $\begin{array}{c}\text { Density } \\
\left(\mathrm{g} \mathrm{cm}^{-3}\right)\end{array}$ & $\begin{array}{c}\text { Hardness } \\
(\text { Brinell })\end{array}$ & $\begin{array}{l}\text { Specific wear } \\
\left(\mathrm{g} \mathrm{mm}^{-2}\right)\end{array}$ \\
\hline UC-4 & 0.394 & 0.0182 & 1.935 & 18.2 & $0.26 \times 10^{-6}$ \\
\hline UC-8 & 0.401 & 0.0172 & 1.842 & 16.2 & $0.27 \times 10^{-6}$ \\
\hline UC-12 & 0.420 & 0.0192 & 1.765 & 15.9 & $0.34 \times 10^{-6}$ \\
\hline UC-16 & 0.427 & 0.0216 & 1.704 & 14.7 & $0.37 \times 10^{-6}$ \\
\hline UC-20 & 0.437 & 0.0223 & 1.680 & 13.9 & $0.38 \times 10^{-6}$ \\
\hline UCH-4 & 0.410 & 0.0091 & 1.834 & 23.2 & $0.21 \times 10^{-6}$ \\
\hline UCH-8 & 0.418 & 0.0127 & 1.782 & 20.3 & $0.22 \times 10^{-6}$ \\
\hline UCH-12 & 0.430 & 0.0127 & 1.717 & 18.9 & $0.29 \times 10^{-6}$ \\
\hline UCH-16 & 0.442 & 0.0140 & 1.652 & 18.2 & $0.33 \times 10^{-6}$ \\
\hline UCH-20 & 0.454 & 0.0134 & 1.588 & 15.3 & $0.35 \times 10^{-6}$ \\
\hline
\end{tabular}

In the present study, no direct proportionality was found among the density, the hardness and the wear resistance due to the complexity of the composite structures. However, the highest friction coefficient was obtained for the UCH-20 sample. This sample includes $4 \%$ of ulexite and $20 \%$ of cashew and it was heat treated. The lowest friction coefficient was obtained for the UC-4 sample. This sample includes $20 \%$ of ulexite and $4 \%$ of cashew and it was heat untreated. In addition, less wear was observed on the heat-treated samples, which included 4-20\% of ulexite and 20-4\% of cashew, and their mean values of the friction coefficients ranged from 0.41-0.45 (Table 3). Besides, the minimum wear was obtained for the UC-4 and UCH-4 samples, including the heat-treated and untreated ones. It is seen from Table 3 that the heat-treated samples generally have a better wear resistance than the untreated samples.

It is also seen from Table 3 that heat treatment facilitated a more homogeneous braking-pad structure. In addition, a more stabilised friction coefficient was obtained due to heat treatment. It is assumed that some detached materials left the samples and then structural variations were obtained. Furthermore, with the increasing temperature the ingredients in the braking pad affected each other due to a faster diffusion. Therefore, it can be said that heat treatment is essential for braking pads. It is also known that the hardness of a sample increases and the density decreases due to heat treatment, while the specific wear ratio changes (Table 3). In the present work, heat treatment facilitated a better performance of all the samples compared with the untreated ones. These results are consistent with the earlier works. ${ }^{32-35}$

As can be seen from Table 3, the friction coefficients achieved for samples UCH-20 and UCH-16 are approximately 0.45 , which is considered to be very good when compared to the coefficients of friction achieved with the current brake pads. The UC-4 sample has the highest density and hardness among the untreated samples. It includes $20 \%$ of ulexite and $4 \%$ of cashew; the specific gravity of ulexite is bigger than that of cashew. A higher amount of ulexite causes a higher density. But the heattreated UCH-4 sample with the same ingredients has the highest hardness among the all samples.

It is well known that the friction coefficient is usually associated with an increase in the wear. In the present work, all the samples confirmed this assumption (Table 3). But the UCH-16 and UCH-20 samples have better values than the other samples. Therefore, one can say that only samples UCH-16 and UCH-20 are preferred for this kind of brake pads as they provide better mechanical and microstructural properties than the other samples.

It can be seen from the results that there is no direct correlation between the wear resistance and the hardness. However, this is an unavoidable reality of these features that affect each other. As can be seen from the table, a high-hardness pad has a high wear resistance and lower wear due to the amounts of the constituent components of the samples. The components made of the pad mate- 
rials comprised of compounds of different contents can have a hard structure and, consequently, a higher hardness. But the amount of the resin component included in the materials is not sufficient as the particle adhesion surface is decreased and there is a quick separation of the particles that make up the main structure at low strains, while the friction can cause a wear that is higher than expected.

The heating process generally affects the microstructure of a brake pad and, accordingly, the hardness increases. It can be seen from Table $\mathbf{3}$ that the friction coefficient of the UC-4 sample is 0.394 and its wear rate is $0.26 \cdot 10^{-6}$ and, after the heat treatment, these values are 0.410 and $0.21 \cdot 10^{-6}$, respectively. The situation is similar for the other samples. Thus, after the heat treatment, the coefficients of friction of the samples of the same ingredients increase and their wear rates decrease. Heat treatment has a positive impact on both the friction coefficient and specific wear.

The mean coefficient of friction, hardness, and wear rates of the heat-treated (UCH) and untreated (UC) samples showing parallelism to each other exhibit the characteristics of the material. The sample with a high mean coefficient of friction also has a high wear rate. In this case, the rubbing of the ruptures of large particles from the brake pad due to the strain has a significant impact. Also, since the pad's hardness is lower than the hardness of the disk, the wear naturally increases during the process of creating a high coefficient of friction. After the heat treatment, the densities of the samples decrease. During the heat treatment at a low evaporation temperature, volatile materials move away from the body and form micro-scale porosity in the body. This situation causes a decrease in the density, and the heat produced during the friction (rubbing) is removed from the body by the micro-pores, leading to a lower friction-surface temperature and a stable friction performance. ${ }^{36}$

\section{CONCLUSIONS}

In this study, the effect of ulexite and cashew amounts on the friction and wear behavior of a brake pad used in the automotive industry is experimentally analyzed. As a result of the experiments, the structure and chemical composition of the friction layer generated on the friction surface differ significantly from those of the bulk. It is apparent that no simple relationship exists between the composition of the friction layer and the bulk-material formulation. Heat treatment facilitated a more homogeneous structure and, hence, microstructural variations were minimized during the braking action. On the other hand, heat treatment increased the hardness of the samples and also decreased the density.

The highest friction coefficient was obtained for the heat-treated samples. Smaller values were obtained for the untreated samples. The UCH-4 sample had a more stable friction coefficient during the FAST than the other samples. As the UCH-4 and UCH-8 samples had lower friction coefficients, their wear ratios and standard deviations were also considerably lower. Out of 10 samples, UC-20, UCH-12, UCH-16 and UCH-20 exhibited better friction and wear properties. Therefore, these samples can be suggested as brake-pad materials.

In the present work, the standard deviation was within the acceptable range for all the samples. No direct proportionality among the mean coefficients of friction, the standard deviation and the wear resistance was found due to the complexity of the composite structures. Some micro-voids and micro-cracks were observed on the worn surfaces.

\section{REFERENCES}

${ }^{1}$ P. J. Blau (ed.), Friction, Lubrication, and Wear Technology, ASM Handbook, vol. 18, ASM International, 1992, 569-577

${ }^{2}$ M. Boz, A. Kurt, Relationship between density and friction coefficient in powder metal bronze brake lining, Proceedings of the second international conference on P/M, Cluj-Napoka, Romania, 2000, 181-187

${ }^{3}$ A. Kurt, M. Boz, Mater. Design, 26 (2005), 717-721, doi:10.1016/ j.matdes.2004.09.006

${ }^{4}$ M. G. Jacko, S. K. Lee, Kirk-Othmer Encyclopedia of Chemical Technology, vol. 4, $4^{\text {th }}$ ed., Wiley, 1992, 523-536

${ }^{5}$ E. W. Reinsch, Sintered Metal Brake Linings for Automotive Applications, chapter 2, In: H. H. Hausner et al. (eds.), Perspectives in Powder Metallurgy Fundamentals, Methods, and Applications, Plenum Press, New York 1970, 9-21, doi:10.1007/978-1-46843015-8_2

${ }^{6}$ J. W. Longley, R. Gardner, IMechE, 453 (1988), 31-38

${ }^{7}$ G. Drava, R. Leardi, A. Portesani, E. Sales, Chemometr. Intell. Lab., 32 (1996), 245-255, doi:10.1016/0169-7439(95)00085-2

${ }^{8}$ P. J. Blau, Compositions, functions, and testing of friction brake materials and their additives, Oak Ridge National Laboratory Technical Report ORNL/TM 2001/64, Oak Ridge, Tennessee, 2001, doi: $10.2172 / 788356$

${ }^{9}$ G. Nicholson, Facts about friction, Gedoran Publishing, Winchester, VA 1995

${ }^{10}$ H. Jang, S. J. Kim, Wear, 239 (2000), 229-236, doi:10.1016/S00431648(00)00314-8

${ }^{11}$ Y. Lu, Compos. Sci. Technol., 66 (2006), 591-598, doi:10.1016/ j.compscitech.2005.05.032

${ }^{12}$ S. Ozcan, P. Filip, Wear, 259 (2005), 642-650, doi:10.1016/j.wear. 2005.02.112

${ }^{13}$ I. Sugozu, I. Mutlu, J. Theor. Appl. Mech., 39 (2009) 1, 101-114

${ }^{14}$ I. Mutlu, J. Appl. Sci., 9 (2009) 2, 377-381

${ }^{15}$ F. Ficici, M. Durat, M. Kapsiz, J. Braz, Soc. Mech. Sci., 36 (2014) 3, 653-659, doi:10.1007/s40430-013-0115-x

${ }^{16}$ K. W. Liew, U. Nirmal, Mater. Design, 48 (2013), 25-33, doi:10.1016/j.matdes.2012.07.055

${ }^{17}$ M. A. Maleque, A. Atiqah, R. J. Talib, H. Zahurin, IJMME, 7 (2012) 2, 166-170

${ }^{18}$ A. Keskin, Sci. Res. Essays, 6 (2011) 23, 4893-4904, doi:10.5897/ SRE10.1072

${ }^{19}$ http://www.boren.gov.tr, accessed 10 September 2013

${ }^{20}$ R. B. Kistler, C. Helvaci, Ind. Min. and Rocks, (1994), 171-186

${ }^{21}$ J. Bijwe, N. M. Nidhi, B. K. Satapathy, Wear, 259 (2005), 1068-1078, doi:10.1016/j.wear.2005.01.011

${ }^{22}$ A. Ganguly, R. George, Bull. Mater. Sci., 31 (2008) 1, 19-22, doi:10.1007/s12034-008-0004-6 


\section{İ. SUGÖZÜ et al.: FRICTION AND WEAR BEHAVIOUR OF ULEXITE AND CASHEW IN AUTOMOTIVE BRAKE PADS}

${ }^{23}$ I. Mutlu, Investigation of some ceramic additive automotive brake pads, Dissertation, University of Sakarya, Turkey, 2002

${ }^{24}$ TS 555 (Turkish Standard), Highway vehicles, brake systems, brake pads for frictional brake, Turkey, 1992

${ }^{25}$ British Standards Specification: BS AU 142-1968, 1968

${ }^{26}$ G. P. Ostermeyer, Wear, 254 (2003), 852-858, doi:10.1016/S00431648(03)00235-7

${ }^{27}$ M. Eriksson, F. Bergman, S. Jacobson, Wear, 232 (1999), 163-167, doi:10.1016/S0043-1648(99)00141-6

${ }^{28}$ K. W. Hee, P. Filip, Wear, 259 (2005), 1088-1096, doi:10.1016/ j.wear.2005.02.083

${ }^{29}$ A. Fischer, Wear, 194 (1996), 238-245, doi:10.1016/0043-1648(95) 06738-8

${ }^{30}$ G. Straffelini, Wear, 245 (2000), 216-222, doi:10.1016/S00431648(00)00481-6
${ }^{31}$ I. Mutlu, I. Sugozu, C. Oner, Investigation of friction behavior of boric acid and black pine cone dust added brake pads, IATS'09, Turkey, 2009

${ }^{32}$ T. R. Champman, D. E. Niesz, R. T. Fox, T. Fawcett, Wear, 236 (1999), 81-87, doi:10.1016/S0043-1648(99)00259-8

${ }^{33}$ S. K. Rhee, M. G. Jacko, P. H. S. Tsang, Wear, 146 (1991), 89-97, doi:10.1016/0043-1648(91)90226-K

${ }^{34}$ J. R. Barber, T. W. Beamond, J. R. Waring, C. Pritchard, J. Tribol., 107 (1985) 2, 206-210, doi:10.1115/1.3261021

${ }^{35}$ T. Matsushima, H. Masumo, S. Ito, M. Nishiwaki, SAE Tech. Paper 982251, (1998), doi:10.4271/982251

${ }^{36}$ I. Sugozu, Production of non-asbestos automotive brake lining additional boron and investigation of its braking characteristic, Dissertation, Univ. of Firat, Turkey, 2009 